\title{
READINESS FOR CHANGE AND JOB SATISFACTION IN A CASE OF LEAN MANAGEMENT APPLICATION - A COMPARATIVE STUDY
}

\author{
AGNIESZKA LIPIŃSKA-GROBELNY and EWELINA PAPIESKA \\ University of Łódź, Łódź, Poland \\ Institute of Psychology, Department of Psychology of Work and Career Guidance
}

\begin{abstract}
Objectives: This current study investigates the effect of lean management system on work attitudes of workers of two manufacturing companies. "Lean management" is a concept of work processes and human relations that determines company's productivity and profitability. Workers of two enterprises, the first one with lean production and the second one with old mass production, were compared for their readiness for change and job satisfaction (both emotional and cognitive aspect). Materials and Methods: The sample of 102 employees completed a battery of instruments such as: the Job Description Inventory by Neuberger and Allerbeck, the Job Affect Scale by Burke et al. and the Change-Readiness Scale by Kriegel and Brandt. Results: Individuals from the lean manufacturing company were characterized by higher level of readiness for change, positive affect at work, and cognitive job satisfaction. Conclusions: In this approach the introduction of lean production positively affected company's human resource attitudes.
\end{abstract}

Key words:

Readiness for change, Job satisfaction, Lean management, Old mass production

\section{INTRODUCTION}

Lean production is also known as lean management or lean manufacturing. Mostly it derives from Frederick Taylor, Henry Ford and the Toyota Production System (TPS). The father of lean manufacturing is assumed to be Taiichi Ohno, who started to work for Toyota Motor Corporation in 1943. Lean production is a concept of transforming human resource management, work processes and industrial relations. Its crucial point is to minimise waste ( $m u d a$ ) in all aspects of firm's production processes [1], in order to achieve better efficiency, responsiveness to clients' requirements, and quality [2].

According to Womack, Jones and Roos [3], lean management involves the transfer of responsibilities, duties and tasks to workers who add value to the product. The maximum transfer of those commitments implies a reorganization of management process and redistribution of power. Moreover, employees are perceived as a strategic resource for productivity improvement. They are trained in a special type of quality control and problem solving. Under mass production, quality is examined after the product has been completed and corrected in the repair shop. In lean production, quality is embedded into the product and problems are solved where they occur [4]. A general misunderstanding is that lean management is appropriate only for production. The fact is that lean management is not only a cost reduction system or a business tactics, but

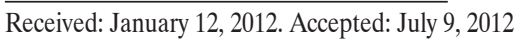

Address reprint request to: A. Lipińska-Grobelny, University of Lódź, Institute of Psychology, Department of Psychology of Work and Career Guidance, Smugowa 10/12, 91-433 Łódź, Poland (e-mail: alipinskagrobelny@gmail.com). 
also is a way of thinking and working for all types of organizations.

Since lean management involves people in business processes and traditional mode of production may reduce job satisfaction and positive attitude to work, in this current study we decided to focus on the effects of lean production on employees' job satisfaction and their readiness for change and compare workers of two enterprises, the first one with lean management and the second one with old mass production.

The discussion about the impact of lean model on employees' results and job characteristics is not determined by empirical evidence. From one point of view, negative consequences have been reported in detailed case studies [e.g. 5,6]. Besides, Landsbergis, Cahill and Schnall [7] also claimed that this practice would cause increased demands and modest, or no changes at all, in decision autonomy. From the opposite point of view, a few authors have shown positive consequences of lean management [e.g. 8,9], or at least a mixture of both negative and positive results [e.g. 10]. One possible explanation for these contradictory findings is the methodological inadequacy of many analyses. Landsbergis, Cahill and Schnall [7] focused on a number of case studies that could generate the lack of control over elements of lean practices being introduced in particular organizational environments. Parker [11] in turn relied on a longitudinal procedure that could be associated with stronger disturbances of causality than other lean management studies. Therefore, we would like to verify the effect of lean production on work attitudes of line workers by comparing two manufacturing companies, the first one that implemented lean management five years ago, and the other one without lean management. These plants represented the same branch, comparable technology and financial standing.

Below we will present the conceptualization of two key concepts: job satisfaction and readiness for change. In accordance with Brief [12], job satisfaction can be described as an internal state related with affectively and/or cognitively assessing a job situation with some degree of approval and disapproval. Brief [12] assumes that job satisfaction derives from the interface of feelings and thoughts, or emotional and cognitive perspectives. The emotional facet of job satisfaction is measured in this study not as a single dimension, but as positive and negative affect at work demonstrated separately [12]. Consecutively, cognitive facet of job satisfaction evaluates global satisfaction with a job and/or satisfaction with several key aspects. Neuberger and Allerbeck [13], whose inventory was implemented in this research, suggest to define satisfaction with respect to seven various components namely: co-workers, supervisor, job content, working facilities, organization and management, opportunities for development, and income.

The second key concept is readiness for change. Kriegel and Brandt [14] characterize a person that is ready to transform as one that is open to new ideas and committed to change as a continuous process [14]. At the same time they describe seven personal characteristics that determine how well a person reacts to change. These characteristics are as follows: confidence, resourcefulness, passion (i.e. cognitive readiness for change), optimism, adventurousness, adaptability (i.e. emotional readiness for change) and tolerance for ambiguity. Confidence is the person's beliefs in having skills to cope with difficult situations. Resourcefulness is the ability to take advantage of whatever resources are available to develop opportunities and make plans. Passion is the individual determination and power. Optimism appraises whether a person possesses a positive view of the future. Adventurous people take a risk and like challenges. Lastly, adaptability and tolerance for ambiguity analyze how well the individual manages changes and the uncertainty that goes along. Kriegel and Brandt [14] state that the particular personal characteristics support the readiness for change. Optimism, adaptability, tolerance for ambiguity, resourcefulness, adventurousness and passion permit individuals to be challenged and excited by 
new experiences and at the same time remain confident and optimistic to handle demanding situations.

\section{OBJECTIVES}

The main concern of this study is the relation of job satisfaction and readiness for change to the lean model. The extent to which lean management differs from the traditional mode of production and its effect on employees' outcomes is disputable. The 2005 study by the Conference Board investigated factors of organizational changes. The results revealed that the degree of success required the organizational capacities to achieve change. The top three success factors were: 1) people issues (e.g. employees' change readiness, job satisfaction, staffing/talent problems and turnover), 2) organizational resistance and 3) communication weaknesses [15]. Chatman and Jehn [16] have found that lean principles can transform working environment and working methods that may influence values and attitudes of employees or enhance their job satisfaction. Some understanding of the workers' view of a new production system can be obtained from a survey by Chapman, Elhance and Wenum [17]. Workers in the lean production company were satisfied with products $(88 \%)$, colleagues $(74 \%)$, working environment (66\%), personnel growth (58\%) and work in general (57\%). In contrast to these results, Parker [11] reported that employees in lean production groups experienced decreased organizational commitment and increased job depression. The negative outcomes of the lean system were partially associated with declines in such work characteristics as participation in decision making and skill utilization. In turn, according to research by Denmark's Technical University (DTU), lean management did not directly affect, in a positive or negative way, employees' job satisfaction while, in the long run, lean production caused a higher degree of job satisfaction and productivity [18].

Regarding the relationship between lean manufacturing and readiness for change, it is worth to mention that lean model involves a holistic attitude to changes. In such a situation, workers become the core of lean processes, because the right perspective of employees and their attitudes toward change are essential for the success of lean transformation. It can be observed in empirical studies. Nordin, Deros and Wahab [19] - as an example - reported that lean production had a positive effect on readiness for change (both among managers and employees), team development, employee training and effective communication. A study of two organizations by Papadopoulou and Ozbayrak [20] also indicated that a systematic lean encouragement and education as well as development of lean culture were essential for sustaining changes and readiness for leanness.

Lean manufacturing is connected with reduced cycle times, lower production waste, change in process sequence and improved quality. As stated before, lean production may affect job satisfaction as well as readiness for change. Hardin [21] reported a statistically significant relationship between job satisfaction and desire for change. An alternative interpretation for such a result would be that readiness for change is a manifestation of the degree of job satisfaction in general or with specific components of the job. It is interesting to see which aspects of job satisfaction affect emotional and cognitive readiness for change when comparing lean model with the traditional mode of production, because they would appear to be important conditions of change of the attitudes in lean practices.

Considering all findings, which are apparently inconsistent in some aspects, we have asked four questions:

1. Is there a difference in readiness for change between employees of organization A (with lean production) and organization $\mathrm{B}$ (with mass production)?

2. Are there differences in emotional and cognitive aspects of job satisfaction between employees of organization A (with lean production) and organization $\mathrm{B}$ (with mass production)? 
3. Are there differences in various components of job satisfaction between employees of organization $\mathrm{A}$ (with lean production) and organization B (with mass production)?

4. Is readiness for change related to employees' job satisfaction in organization A (with lean production) and organization $\mathrm{B}$ (with mass production)?

\section{PARTICIPANTS AND MEASURES}

\section{The examined groups}

The research was carried out in a group of 102 assembly line workers (only men) of two organizations from heavy industry, the first one (A) with lean production (61 men, aged 24-59, with a mean age of 45 years) and the second one (B) with old mass production (41 men, aged 21-59, with a mean age of 48 years). The average work experience in the job was 15 years for employees from the organization A and 14 years for employees from the organization B. Most of the participants were married (76\% in plant $\mathrm{A}$ and $87 \%$ in plant B). A majority of employees from the organization A had a secondary (42\%) and a vocational (49\%) education. As for employees from the organization B, a straight majority comprised persons with a vocational education (79\%). These organizations represented the same branch, comparable financial standing and technology. Plant A has been implementing the lean process (i.e. decreased cycle time, increased productivity and capital equipment utilization) for five years already, long enough to observe the consequences of the changes. The results were analysed using SPSS 14.0. software package.

\section{Study techniques}

In order to answer the questions, the following psychometrically verified paper-pencil tests were used:

1. Job Description Inventory by Neuberger and Allerbeck [13], that measures satisfaction with respect to different components of employees' overall job satisfaction, namely co-workers, supervisor, job content, working facilities, organization and management, opportunities for development, income. Coefficient alpha ranges from 0.69 to 0.92 .

2. Job Affect Scale by Brief et al., [22] that is composed of 20 clear markers of positive and negative affect at work. Ten items are markers of negative affect and other 10 items are markers of positive affect. Coefficient alpha for the positive affect equals 0.84 and for the negative affect it equals 0.79 .

3. Change-Readiness Scale by Kriegel and Brandt [14], that describes cognitive readiness for change (i.e. confidence, resourcefulness, passion) and emotional readiness for change (i.e. optimism, adventurousness, adaptability). Due to the fact that loading of tolerance for ambiguity was at the level under 0.40 , this personal characteristic was excluded from the scale. Coefficient alpha ranges from 0.64 (emotional readiness for change) to 0.75 (cognitive readiness for change).

\section{RESULTS}

\section{Employees' readiness for change - comparative study}

To explore the impact of lean management on employees' readiness for change, the t-test was used, followed by calculating the effect size Cohen's d. The scores are

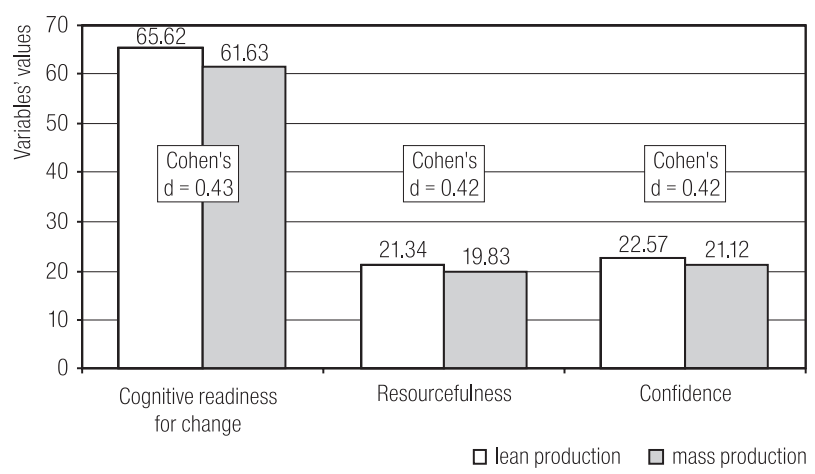

Fig. 1. Readiness for change (mean values) in organization A (with lean production) and organization $\mathrm{B}$ (with mass production), $(\mathrm{N}=102)$ 
presented in Figure 1. The results indicate that employees from the organization A differ significantly compared with employees from organization $B$ on their levels of cognitive readiness for change $[\mathrm{t}(100)=2.14, \mathrm{p}=0.035]$, resourcefulness $[\mathrm{t}(100)=2.13, \mathrm{p}=0.036]$, and confidence $[t(100)=2.09, p=0.039]$. Cohen's d around 0.5 indicates medium effect of lean management on readiness for change and its two partial variables.

\section{Job satisfaction (both emotional and cognitive aspect) - comparative study}

The t-test was also applied to estimate the effect of lean management on cognitive and emotional aspect of job satisfaction (both positive and negative affectivity), (Figure 2). Results demonstrate that employees (from lean and traditional mode of production) differ on their display

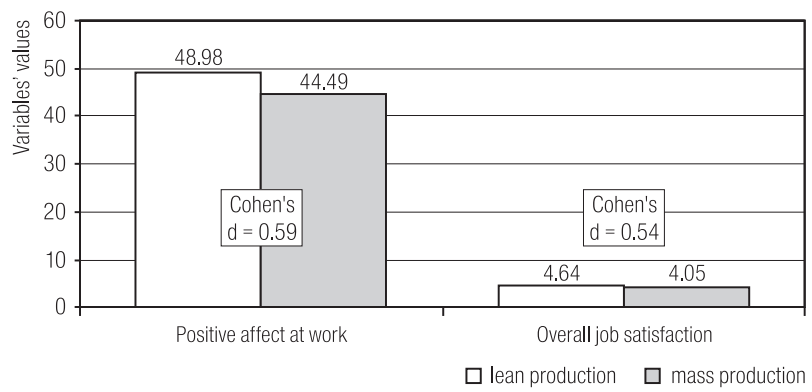

Fig. 2. Job satisfaction (mean values) in organization $\mathrm{A}$ (with lean production) and organization $\mathrm{B}$ (with mass production), $(\mathrm{N}=102)$

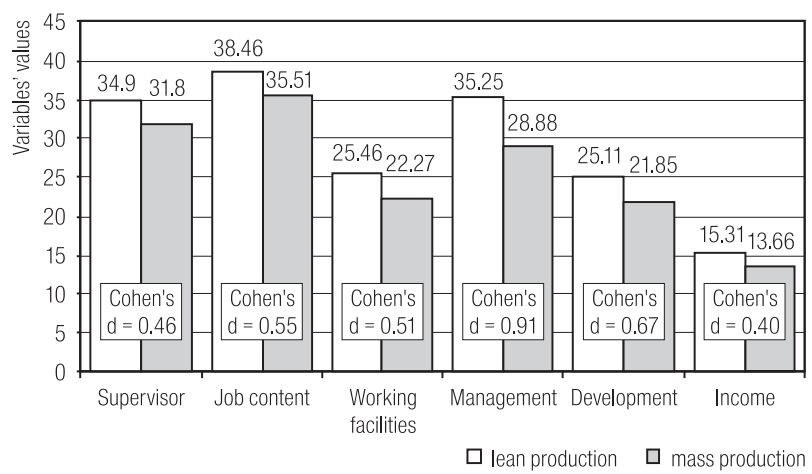

Fig. 3. Different components of job satisfaction (mean values) in organization $\mathrm{A}$ (with lean production) and organization $\mathrm{B}$ (with mass production), $(\mathrm{N}=102)$ of positive affect at work [ $\mathrm{t}(100)=2.93, \mathrm{p}=0.004]$, and the overall job satisfaction $[t(100)=2.69, p=0.008]$. The strongest positive affect $(\mathrm{M}=48.98)$ and overall job satisfaction $(\mathrm{M}=4.64)$ refer to employees from organization with lean manufacturing. Cohen's $\mathrm{d}$ around 0.5 indicates medium effect of lean management on emotional and cognitive aspect of job satisfaction.

\section{Different components of job satisfaction - comparative study}

An identical procedure was used to examine the influence of lean management on different components of job satisfaction. These analyses are presented in Figure 3. The t-test has revealed that employees from lean production enterprise differ significantly on their levels of satisfaction with supervisor $[\mathrm{t}(100)=2.33$, $\mathrm{p}=0.022]$, job content $[\mathrm{t}(100)=2.77, \mathrm{p}=0.007]$, working facilities $[\mathrm{t}(100)=2.55, \mathrm{p}=0.012]$, organization and management $[\mathrm{t}(100)=4.54, \mathrm{p} \leq 0.001]$, opportunities for development $[\mathrm{t}(100)=3.36, \mathrm{p}=0.001]$ and income $[\mathrm{t}(100)=1.99, \mathrm{p}=0.05]$. Employees from the lean manufacturing company in comparison with employees from the mass production company are characterized by higher level of satisfaction with organization and management $(\mathrm{M}=35.25)$, opportunities for development $(\mathrm{M}=25.11)$, job content $(\mathrm{M}=38.46)$, working facilities $(\mathrm{M}=25.46)$, supervisor $(\mathrm{M}=34.90)$ and income $(\mathrm{M}=15.31)$. Cohen's $\mathrm{d}$ of 0.8 indicates large effect of lean production on perception of management and medium effect of lean manufacturing on the remaining job satisfaction components.

\section{Readiness for change and job satisfaction - comparative study}

The Pearson product-moment correlations were computed to determine the degree of association between employees' readiness for change and job satisfaction in 
Table 1. Readiness for change and job satisfaction in organization A (with lean production) and organization B (with mass production), $(\mathrm{N}=102)$

\begin{tabular}{lcccc}
\hline \multirow{2}{*}{ Job satisfaction } & \multicolumn{2}{c}{ Organization A } & \multicolumn{2}{c}{ Organization B } \\
\cline { 2 - 5 } & $\begin{array}{c}\text { emotional readiness for } \\
\text { change }\end{array}$ & $\begin{array}{c}\text { cognitive readiness for } \\
\text { change }\end{array}$ & $\begin{array}{c}\text { emotional readiness for } \\
\text { change }\end{array}$ & $\begin{array}{c}\text { cognitive readiness for } \\
\text { change }\end{array}$ \\
\hline Positive affect & $\mathrm{ns}$ & $0.46^{* *}$ & $\mathrm{~ns}$ & $\mathrm{~ns}$ \\
Negative affect & $\mathrm{ns}$ & $-0.31^{*}$ & $\mathrm{~ns}$ & $\mathrm{~ns}$ \\
Co-workers & $\mathrm{ns}$ & $0.31^{*}$ & $\mathrm{~ns}$ & $\mathrm{~ns}$ \\
Supervisor & $\mathrm{ns}$ & $0.26^{*}$ & $\mathrm{~ns}$ & $\mathrm{~ns}$ \\
Job content & $\mathrm{ns}$ & $0.27^{*}$ & $\mathrm{~ns}$ & $\mathrm{~ns}$ \\
Working facilities & $-0.35^{* *}$ & $\mathrm{~ns}$ & $\mathrm{~ns}$ & $\mathrm{~ns}$ \\
Management & $\mathrm{ns}$ & $\mathrm{ns}$ & $\mathrm{ns}$ & $\mathrm{ns}$ \\
Development & $\mathrm{ns}$ & $\mathrm{ns}$ & $\mathrm{ns}$ & $-0.31^{*}$ \\
Income & $\mathrm{ns}$ & $\mathrm{ns}$ & $0.40^{*}$ & $\mathrm{~ns}$ \\
Overall job satisfaction & $\mathrm{ns}$ & $\mathrm{ns}$ & $\mathrm{ns}$ & $\mathrm{ns}$ \\
\hline
\end{tabular}

ns - nonsignificant.

${ }^{*} \mathrm{p}<0.05 ; * \mathrm{p}<0.01 ; * * \mathrm{p}<0.001$.

organization A with lean production and organization $\mathrm{B}$ with old mass production (Table 1).

In lean production company positive affect at work, satisfaction with co-workers, supervisor, job content are positively, with a moderate effect size (around $r=0.30$ ), associated with cognitive readiness for change. Negative affect $(\mathrm{r}=-0.31)$ is negatively associated with cognitive readiness for change, while working facilities $(\mathrm{r}=-0.35)$ are negatively associated with emotional readiness for change. In old mass production company there are moderate but significant relationships between income and employees' emotional readiness for change $(\mathrm{r}=0.4)$ and between opportunities for development and employees' cognitive readiness for change $(r=-0.31)$.

\section{DISSCUSION}

The general purpose of this research was to find out whether lean management had a positive or negative influence on workers' attitudes and job satisfaction. This article pertains to the debate on effects of lean principles on job

quality and employees' outcomes. As we have mentioned before, results are rather inconsistent. From one point of view, negative consequences have been described in several case studies [e.g. 5-7]. From the opposite point of view a few studies have shown positive consequences of lean management [e.g. 8,9], or at least a mixture of both negative and positive results [e.g. 10]. Sceptics do not treat lean manufacturing as more humane system, but as intensified mass production or neo-Taylorism [11]. They even apply new terms for lean management such as management by stress or mean production to emphasize negatives results for workers' well-being and their motivation.

The present study demonstrates that employees from the lean manufacturing company in comparison with employees from the mass production company were characterized by higher level of cognitive readiness for change, resourcefulness and confidence, positive affect at work and overall job satisfaction. They were also more satisfied with organization and management, opportunities for development, job content, working facilities, supervisor and income. The question is why? It is suggested 
that the reason for the enhanced readiness for change and partial job satisfactions in the lean plant is the employee participation in decision making and the degree to which workers have influence over more distant issues that concern their task and obligations [23]. Moreover in organization $\mathrm{A}$ with the lean production employees were more ready for change when they were more satisfied with job content, supervisor, co-workers, dissatisfied with working facilities, and possessed strong positive and weak negative affectivity. In organization B with the mass production employees were more ready for change when they were more satisfied with income and dissatisfied with opportunities for development. This research is a comparison between two enterprises from heavy industry with similar manufacturing conditions. In this study the introduction of lean manufacturing positively affected human resource attitudes and job satisfaction. The results point to different approaches that are needed to facilitate change. It is presumed that employees are more ready for change when they are dissatisfied [24]. We have found that job dissatisfaction is important but the solid ground for change generates satisfaction with several aspect of work such as job content, supervisor, co-workers in organization with lean production and satisfaction with income in organization with mass production. Furthermore, the findings of our current study support the conjecture that the company's managers are considerably anxious about whether the lean process would be effective or fail, because they must identify, hire, train and retrain the right kind of workers [25].

With regard to these results, lean management is viewed as a basis for work motivation to facilitate innovative behaviors of workers and their change readiness. This demand for lean model necessitates organizational structure that supports innovative behaviors and total quality, problem-solving activities, development of employees (such as on-the-job training, job rotation, skill certification programmes), and working under skilled team leaders. Unless those requirements are satisfied, the employees are not likely to develop those spontaneous innovative attitudes. Should we invest in lean management? The decision to move forward is much easier to make if lean is administered as a competitive strategy for increased market share and improving profit growth. Reductions in costs and inventory are also important advantages. In the light of these arguments, the choice of implementation of lean management is sometimes the choice between higher productivity-profitability or solvency-survival. If a company wishes to thrive in today's competitive market, lean management may help to achieve that goal.

\section{REFERENCES}

1. Sun S. The strategic role of lean production in SOE's Development. Int J Business Manag 2011;6:160-8.

2. Applebaum E, Batt R. The new American workplace: Transforming work systems in the United States. Ithaca, NY: ILR Press; 1994.

3. Womack JP, Jones DT, Roos D. The machine that changed the world. New York: Macmillan; 1990.

4. Taira K. Compatibility of human resource management, industrial relations, and engineering under mass production and lean production: an exploration. Appl Psychol 1996;45:97-117.

5. Fucini J, Fucini S. Working for the Japanese: Inside Mazda's American auto plant. New York: Free Press; 1990.

6. Parker M, Slaughter J. Choosing sides: Unions and team concept. Boston: South End Press; 1988.

7. Landsbergis PA, Cahill J, Schnall P. The impact of lean production and related new systems of work organization on worker health. J Occup Health Psychol 1999;4:108-30.

8. Adler PS, Cole RE. Designed for learning: A tale of two auto plants. Sloan Manag Rev 1993;34:85-94.

9. Mullarkey S, Jackson PR, Parker SK. Introducing JIT within product-based work-teams. Int J Operat Product Manag 1995;15:62-79. 
10. Jackson PR, Mullarkey S. Lean production teams and health in garment manufacture. J Occup Health Psychol 2000;5:231-45.

11. Parker SK. Longitudinal effects of lean production on employees outcomes and mediating role of work characteristics. J Appl Psychol 2003;4:620-34.

12. Brief AP. Attitudes in and around organizations. Thousand Oaks, CA: Sage; 1998.

13. Neuberger O, Allerbeck M. Measurement and Analysis of Satisfaction with Work. Bern, Stuttgart, Wien: Rubber; 1978 [in German].

14. Kriegel R, Brandt D. Sacred cows make the best burgers. Developing change-ready people and organizations. New York: Warner Books; 1996.

15. Change management: the HR strategic imperative as a business partner. HR Magazine 2007;01 December [cited 2012 January 4]. Available from URL: http://goliath.ecnext.com/coms2/ gi_0199-7310774/Change-management-theHR-strategic.html.

16. Chatman JA, Jehn KA. Organizational culture in the service sector: A between-industry comparison. Evanston: Northwestern University; 2001.

17. Chapman ML, Elhance AP, Wenum JD. Mitsubishi Motors in Illinois: Global strategies, local impacts. Westport, CT: Quorum Books; 1995.

18. Unchanged job satisfaction with "Lean". NordKraft 2010;24 January [cited 2012 January 6]. Available from URL: http:// nordkraft.biz/unchanged-job-satisfaction-with-lean.
19. Nordin N, Deros BM, Wahab DA. Relationship between organizational change and lean manufacturing implementation in Malaysian automotive industry. The 14th Asia Pacific Regional Meeting of International Foundation for Production Research; 2010 Dec 7-10, Melaka, Malaysia [cited 2012 January 5]. Available from URL: http://apiems.net/archive/ apiems2010/ pdf/LM/19.pdf.

20. Papadopoulou TC, Ozbayrak M. Leanness: experience from the journey to date. J Manufact Technol Manag 2005;16: 784-807.

21. Hardin E. Job satisfaction and the desire for change. J Appl Psychol 1967;16:20-7.

22. Brief AP, Burke MJ, George JM, Robinson B, Webster J. Should negative affectivity remain an unmeasured variable in the study of job stress? Journal of Applied Psychology 1988;73:193-198.

23. Adler PS. The "learning bureaucracy": New United Motor Manufacturing. In: Staw BM, Cummings LL, editors. Research in organizational behavior. Greenwich, CT: JAI Press; 1993. p. 111-94.

24. Beckhard R, Harris R. Organizational Transitions: Managing Complex Change. Reading, MA: Addison-Wesley; 1987.

25. Brofenbrenner M. An essay on negative screening. In: Shishido T, Sato I, Okita S, editors. Economic policy and development: new perspectives. London: Croom Helm; 1985. p. $188-98$.

This work is available in Open Access model and licensed under a Creative Commons Attribution-NonCommercial 3.0 Poland License - http://creativecommons.org/ licenses/by-nc/3.0/pl/deed.en. 